\title{
PENGARUH MOTIVASI, PERSEPSI DAN SIKAP KONSUMEN TERHADAP KEPUTUSAN PEMBELIAN JARINGAN INTERNET PADA PT TELEKOMUNIKASI INDONESIA DI KOTA BATAM
}

\author{
Mohammad Anano $^{1^{*}}$, Nora Pitri Nainggolan ${ }^{2}$ \\ ${ }^{1}$ Alumni, Universitas Putera Batam \\ ${ }^{2}$ Dosen Universitas Putera Batam \\ e-mail: muhammadanano84gmail.com
}

\begin{abstract}
In the current era of globalization, business development has been characterized by various kinds of competition in all fields of business. Seeing these needs causes entrepreneurs to increasingly demand the right strategy to meet sales targets. This study aims to discuss partially, Motivation towards internet network purchasing decisions at PT Telekomunikasi Indonesia, and discuss partially. PT Telekomunikasi Indonesia, discussed some of the consumer attitudes towards internet network purchasing decisions at PT Telekomunikasi Indonesia and assessed simultaneously motivational motivation, perceptions and attitudes of consumers towards internet network purchasing decisions at PT Telekomunikasi Indonesia. The method used in this study is a linear multiple regression analysis method. The research design used was descriptive analysis. The test consists of validity test, reliability test, classic assumption test, multiple regression analysis, coefficient of determination, $t$-test and $f$-test. The population in this study were consumers of PT Telekomunikasi Indonesia with a total sample of 384 people. By using the SPSS version 21 software program. The conclusion is the partial variable motivation, Perception and Attitude of Customers has a significant effect on Purchasing Decisions, simultaneously the variables of motivation, perception and attitudes of consumers have a significant effect on internet network purchasing decisions at PT Telekomunikasi Indonesia
\end{abstract}

Keywords: Motivation, Perception, Consumer Attitudes, Purchasing Decisions.

\section{PENDAHULUAN}

Setiap perusahaan harus memahami perilaku konsumen pada pasar sasarannya karena kelangsungan hidup perusahaan tersebut sebagai organisasi yang berusaha memenuhi kebutuhan dan keinginan para konsumen sangat tergantung pada perilaku konsumen nya. Pernyataan ini di dukung oleh (Fahmi, 2016: 1) perilaku konsumen ngacu pada segala tindakan yang dilakukan untuk memahami tingkah laku yang dilakukan dalam produk. khususnya agar bisa bersaing dalam era globalisasi ini, motivasi pada dasarnya guna untuk kepada para pengusaha mikro, kecil dan menengah, tetapi juga menerima simpanan dari masyarakat. Dalam penyaluran kredit kepada masyarakat.

Meningkatkan penjualan dengan memotivasi konsumen Dengan adanya konsep motivasi diharapkan dapat memberikan peningkatkan penjualan. Banyak konsumen termotivasi dengan faktor faktor internal yaitu dari dalam diri dan faktor eksternal yaitu dari lingkungan sekitar yang membuat individu itu termotivasi unttuk memiliki atau membeli sesuatu. Pernyataan ini didukung oleh (Merna M.M. Tomponu, 2014: 620) menyatakan bahwa motivasi berpengaruh signifikan terhadap keputusan pembelian. Dalam meningkatkan pendapata perusahaan.

Persepsi merupakan pendapat seseorang atau individu terhadap suatu barang atau perusahaan melalui apa yang di lihat dan apa yang di dengar oleh individu atau kelompok. 
Pernyataan ini didukung oleh (sisilya Truly Retor, 2014: 678) menyatakan bahwa persepsi memiliki pengaruh signifikan terhadap keputusan pembelian. Sikap konsumen juga dapat menentukan keputusan pembelian sikap konsumen adalah tanggapan atau perasaan suka atau tidak suka terhadap suatu barang atau produk yang di tawarkan kepada konsumen. untuk meningkatkan penjualan sebaiknya sikap konsumen terhadap produk yang di tawarkan harus lah baik. Perny

ataan ini di dukung oleh (Steffi Gunawan, 2015: 162) menyatakan bahwa sikap konsumen berpengaruh signifikan terhadap keputusan pembelian.

Keputusan pembelian tinggi terhadap suatu barang yang di tawarkan menghasilkan pendapatan yang maksimal bagi suatu perusahaan. Jika perusahaan merasakan dampak dari motivasi, persepsi dan sikap konsumen maka dapat dijadikan sebagai salah satu solusi bagi perusahaan untuk menjadi lebih maju. Pernyataan ini didukung oleh (Merna M.M. Tomponu, 2014: 620) menyatakan motivasi, persepsi, pembelajaran, serta sikap berpengaruh signifikan terhadap keputusan pembelian konsumen baik secara parsial maupun simultan.

Memberikan motivasi, persepsi dan sikap konsumen secara bersamaan diyakini dapat memberikan hasil dan profit bagi perusahaan dikarenakan telah terjadi keputusan pembelian. Pernyataan ini didukung oleh (Sisilya Truly Rector, 2014: 674) menyatakan bahwa Motivasi, Persepsi dan Sikap Konsumen memiliki pengaruh positif terhadap Keputusan Pembelian. Untuk dapat meningkatkan Keputusan Pembelian adalah pemberian motivasi, Persepsi, Sikap Konsumen secara efektif.

Adapun tujuan dalam penelitian ini untuk mengetahui:

1. Pengaruh variabel motivasi konsumen secara parsial terhadap keputusan pembelian jaringan internet pada PT Telekomunikasi Indonesia di Kota Batam?

2. Pengaruh variabel persepsi konsumen secara parsial terhadap keputusan pembelian jaringan internet pada PT Telekomunikasi Indonesia di kota Batam?

3. Pengaruh variabel sikap konsumen secara parsial terhadap keputusan pembelian jaringan internet pada PT Telekomunikasi Indonesia di kota Batam?

4. Pengaruh variabel motivasi, persepsi dan sikap konsumen secara simultan terhadap keputusan pembelian jaringan internet pada PT Telekomunikasi Indonesia di kota Batam?

Sikap dinamis motivasi konsumen, perbedaan persepsi,dan sikap selektif konsumen terhadap suatu produk, serta sikap konsumen terhadap suatu produk yang didasari oleh pengalaman pribadi merupakan pokok bahasan yang mendasari penelitian ini, sehingga dapat di ketahui faktor-faktor yang mempengaruhi keputusan pembelian jaringan internet

Oleh karena itu, faktor pendorong dari seseorang untuk melakukan suatu aktivitas tertentu pada umumnya adalah kebutuhan serta keinginan orang tersebut. PT Telekomunikasi Indonesia adalah provider milik BUMN yang menyediakan jaringan internet. Yang berdiri sejak 6 juli 1965 yang berada di Telkom Indonesia - Kantor Daerah Telekomunikasi JL. Jaksa Agung R. Suprapto SH., Sekupang. PT Telekomunikasi Indonesia menyediakan jaringan internet untuk berbagai kalangan seperti perusahaan, perkantoran, perumahan dan lain lain.

Masalah yang sering dihadapi adalah banyak marketing tidak memotivasi calon konsumen sehingga masyarakat tidak tertarik untuk membeli apa yang di tawarkan marketing. Turunnya motivasi konsumen di sebabkan oleh kurangnya pendekatan terhadap pihak marketing, contohnya pihak marketing kurang sering mengunjungi pelanggan yang mengalami gangguan terhadap jaringan internet, kurang nya menawarkan produk secara personal dan mengunjungi rumah-rumah calon konsumen dan kurangnya sosialisasi terdadap lingkungan yang berpotensi positif terhadap pemasangan jaringan internet.

\section{TINJAUAN PUSTAKA}

Motivasi

Menurut (Suryani, 2013: 22) Motivasi adalah konsumen bergerak membeli suatu yang diinginkan karna adanya dorongan. Setiap aktivitas yang dilakukan seseorang pasti memiliki 
suatu faktor yang mendorong aktivitas tersebut. Oleh karena itu, faktor pendorong dari seseorang untuk melakukan suatu aktivitas tertentu pada umumnya adalah kebutuhan serta keinginan orang tersebut.

Persepsi

Menurut (Fahmi, 2016: 11) Persepsi Adalah segala reaksi yang timbul dari setiap rangsangan yang di amati oleh panca indra dan hasilnya adalah memutuskan sesuai dengan reaksi

Sikap Konsumen

Menurut (suryani, 2013: 120) adalah suatu hal yang dipelajari untuk memberikan tanggagapan kepada suatu objek dalam bentuk rasa yaitu suka atau tidak suka.

Keputusan Pembelian

Menurut (Merna M.M. Tompunu, 2014: 612) Keputusan adalah konsep dimana konsumen memeutuskan untuk bertindak melakukan sesuatu untuk melakukan pemebelian memanfaatkan suatu poduk atau jasa.

\section{Penelitian Terdahulu}

Penelitian terdahulu sangat penting sebagai dasar dalam rangka menyusun skripsi ini. 1. Hizkia Elfran Mawey, 2013) Motivasi, Persepsi dan Sikap konsumen Pengaruhnya terhadap Keputusan Pembelian Produk PT. Rajawali Nusindo Cabang Manado, ISSN: 23031174, Tujuan penelitian ini untuk mengetahui pengaruh secara simultan dan parsial dari motivasi, persepsi dan sikap terhadap keputusan pembelian konsumen. Metode penelitiannya adalah asosiatif dengan teknik analisis regresi linier berganda. Penarikan sampel sebanyak 50 responden dari populasi 359 konsumen. Hasil penelitian menunjukkan secara simultan dan parsial variabel motivasi, persepsi, dan sikap berpengaruh positif dan signifikan terhadap keputusan pembelian konsumen. Perusahaan sebaiknya memperhatikan sisi psikologis konsumen dari segi motivasi, persepsi dan sikap konsumennya, sehingga dapat meningkatkan keputusan pembelian konsumen, mempertahankan serta meningkatkan penjualan.

2. (Merna M. M. Tompunu, 2014) Analisis Motivasi, pembelajaran, dan Sikap Konsumen Pengaruhnya terhadap Keputusan Pembelian di KFC Bahu Mall Manado, ISSN: 2303-1174, Tujuan penelitian adalah untuk menganalisis pengaruh motivasi, persepsi, pembelajaran, dan sikap konsumen terhadap keputusan pembelian KFC Bahu Mall Manado. Populasi dalam penelitian ini adalah konsumen yang membeli produk KFC di Bahu Mall. Sampel dalam penelitian sebanyak 84 responden. Teknik pengambilan sampel purposif sampling. Analisis data menggunakan regresi linear berganda. Hasil penelitian menunjukkan motivasi, persepsi, pembelajaran, serta sikap berpengaruh signifikan terhadap keputusan pembelian konsumen baik secara parsial maupun simultan. Manajemen KFC sebaiknya memperhatikan psikologi, persepsi, pembelajaran, sikap konsumen, karena keempat variabel tersebut berpengaruh signifikan terhadap keputusan pembelian di waralaba KFC Bahu Mall Manado.

3. (Sisilya Truly Retor, 2014) Analisis Motivasi, persepsi, Pembelajaran, dan Sikap Terhadap Keputusan Pembelian Pada PT Conbloc Indonesia Surya Manado, ISSN: 2303-1174, Tujuan penelitian ini untuk mengetahui pengaruh Motivasi, Persepsi, Pembelajaran, Keyakinan dan Sikap terhadap Keputusan Pembelian Paving Block pada PT. Conbloc Indonesia Surya Cabang Manado. Penelitian ini menggunakan teknik analisis regresi linear berganda dan skala likert. Sampel yang digunakan 66 responden dari populasi sebanyak 194 konsumen, berdasarkan teknik probability sampling. Hasil penelitian menunjukkan Motivasi, Persepsi, Pembelajaran, Keyakinan dan Sikap bepengaruh terhadap Keputusan Pembelian Paving Block pada PT. Conbloc Indonesia Surya Cabang Manado. Variabel yang dominan berpengaruh adalah Sikap konsumen terhadap keputusan pembelian. Manajemen perusahaan harus tetap menjaga kualitas dan melakukan langkah inovatif dalam konsep dan desain, karena produk yang ditawarkan perusahaan dapat menjadi salah satu pembentukan motif pembelian, persepsi kualitas produk, pembelajaran, serta sikap dalam melakukan keputusan pembelian. 
4. (Arthur Adilang, Sem G. Oroh dan S. Moniharapon, 2014) Persepsi, Sikap, Motivasi Hedonis Terhadap Keputusan Pembelian Produk Fashion Secara Online, ISSN; 2303-1174, Tujuan penelitian ini adalah untuk mengetahui pengaruh Persepsi, sikap, motivasi hedonis terhadap keputusan pembelian. Jenis Penelitian yang digunakan dalam penelitian ini merupakan penelitian asosiatif. Alat analisis yang digunakan dalam penelitian ini adalah analisis regresi berganda. Populasi dalam penelitian ini sebanyak 1.047 Mahasiswa jurusan manajemen Fakultas Ekonomi, sampel dari penelitian ini adalah 50 orang responden yang aktif melakukan transaksi belanja online. Hasil penelitian menunjukkan bahwa persepsi, sikap, motivasi belanja hedonis berpengaruh secara simultan dan parsial terhadap keputusan pembelian. Disarankan bagi penjual yang berkecimpung dalam usaha belanja online agar memperhatikan faktor-faktor psikologis pribadi, sehingga konsumen akan merasa puas dan akan kembali lagi untuk melakukan pembelian ulang.

5. (Angga Arif Wibowo, Achmad Zaini, 2017) Pengaruh Motivasi, Persepsi, dan Sikap Terhadap Keputusan Pembelian Pada Distro The Doff di kota pasuruan, ISSN: 2407-3741, Penelitian ini bertujuan untuk mengetahui pengaruh motivasi, persepsi dan sikap terhadap keputusan pembelian di toko The Doff. Penelitian ini menggunakan metode explanatory research dengan menggunakan pendeketan kuantitatif. Populasi penelitian ini adalah konsumen Toko The Doff di bulan Mei - Juni 2017. Pengumpulan data menggunakan kuesioner kepada 86 responden yang telah ditentukan menggunakan teknik purposive sampling. Analisa data menggunakan regresi linier berganda, uji t dan uji F. Hasil penelitian menunjukkan bahwa, motivasi berpengaruh terhadap keputusan pembelian. Persepsi berpengaruh dengan terhadap keputusan pembelian. Sikap berpengaruh terhadap keputusan pembelian. Pengaruh motivasi, persepsi dan sikap terhadap keputusan pembelian di Toko The Doff sedangkan sisanya dipengaruhi oleh faktor lain diluar penelitian. Berdasarkan hasil penelitian Motivasi, Persepsi dan Sikap terhada Keputusan Pembelian. Saran yang dapat diberikan untuk pihak perusahaan sebaiknya mempertahankan dan meningkatkan motivasi, persepsi dan sikap konsumen agar mampu meningkatkan tingkat pembelian konsumen

\section{METODE}

Metode penelitian yang digunakan dalam penelitian ini adalah metode penelitian kuantitatif. Metode penelitian kuantitaf yaitu penelitian yang digunakan untuk meneliti populasi dan sampel tertentu dan menggunakan pengumpulan data dengan instrument penelitian yang bertujuan untuk menguji hipotesis yang telah ditetapkan (Sugiyono, 2012:8). Untuk olah hasil data digunakan teknik anlisis regresi linear berganda. Dan nantinya akan diuji: Uji Validitas, Uji Reliabilitas, Uji Normalitas, Uji Koefisien Determinasi (R2), Uji T (Parsial) dan Uji F (Simultan).

Lokasi pelaksanaan penelitian ditetapkan pada PT Telekomunikasi Indonesia Berada di JL. Jaksa Agung R. Suprapto SH., Sekupang Kota Batam. 


\section{HASIL DAN PEMBAHASAN}

Analisis ini menggunakan software program versi SPSS 21.

Hasil Uji Validitas

\begin{tabular}{c|c|c|c|c}
\hline Variabel & Pernyataan & r hitung & r tabel & Keterangan \\
\hline & X1_1 & 0,780 & 0,113 & Valid \\
Motivasi & X1_2 & 0,803 & 0,113 & Valid \\
(X1) & X1_3 & 0,718 & 0,113 & Valid \\
& X1_4 & 0,716 & 0,113 & Valid \\
Persepsi & X2_1 & 0,632 & 0,113 & Valid \\
(X2) & X2_2 & 0,638 & 0,113 & Valid \\
& X2_3 & 0,678 & 0,113 & Valid \\
Sikap Konsumen & X2_4 & 0,625 & 0,113 & Valid \\
(X3) & X3_1 & 0,507 & 0,113 & Valid \\
& X3_2 & 0,703 & 0,113 & Valid \\
L3_3 & 0,649 & 0,113 & Valid \\
(Y) & X3_4 & 0.442 & 0,113 & Valid \\
Y_1 & Valid & Valid \\
& Y_2 & 0,647 & 0,113 & Valid \\
\hline
\end{tabular}

Berdasarkan hasil uraian tabel 1 diatas dapat disimpulkan bahwa keselutuhan indicator Motivasi (X1), persepsi (X2) sikap konsumen (X3)dan keputusan pembelian (Y) masingmasing memiliki $r$ hitung $>r$ tabel sehingga dapat dinyatakan valid.

Hasil Uji Reliabilitas

Tabel 2. Hasil Uji Reliabilitas Data

\begin{tabular}{l|c|c}
\hline \multicolumn{1}{c|}{ Variabel } & Alpha Cronbach's & Standard \\
\hline Motivasi (X1) & 0,743 & 0,60 \\
Persepsi (X2) & 0,527 & 0,60 \\
Sikap Konsumen (X3) & 0,337 & 0,60 \\
Keputusan Pembelian (Y) & 0,570 & \\
\hline
\end{tabular}

Berdasarkan uraian tabel 2 diatas dapat disimpulakn bahwa indikator Motivasi (X1) memiliki Cronbach's 0,741, Persepsi (X2) memiliki Cronbach's 0,524, sikap konsumen (X3) memiliki Cronbach's 0,337 dan Keputusan Pembelian(Y) memiliki Cronbach's 0,570 memenuhi uji realibilitas karena dilihat dari angka Alpha Cronbach's >0.6. 
Hasil Uji Normalitas

Tabel 3. Hasil Uji Normalitas One Sample Kolmogorov Smirnov tes

\begin{tabular}{ll|r}
\hline & & Unstandardized Residual \\
\hline $\mathrm{N}$ & & 384 \\
Normal Parameters & Mean & 0.000000 \\
Most Extreme Differences & Std. Deviation & 1.28612017 \\
& Absolute & .043 \\
& Positive & .043 \\
Test Statistic & Negative & -.039 \\
Asymp. Sig. (2-tailed) & & .849 \\
& & $.468^{\mathrm{c}, \mathrm{d}}$
\end{tabular}

Berdasarkan hasil tabel 3 diatas dapat dimpulkan bahwa nilai residual berdistribusi normal. Hal ini dapat dilihat dari nilai signifikan sebesar $0,468>0.005$. maka data dapat disimpulkan telah memenuhi asumsi normalitas.

Hasil Uji Multikolinearitas

Tabel 4. Hasil Uji Multikolinearitas

\begin{tabular}{|c|c|c|c|c|c|c|c|}
\hline \multirow[t]{2}{*}{ Model } & \multicolumn{2}{|c|}{$\begin{array}{l}\text { Unstandardized } \\
\text { Coefficients }\end{array}$} & \multirow{2}{*}{$\begin{array}{c}\begin{array}{c}\text { Standardized } \\
\text { Coefficients }\end{array} \\
\text { Beta }\end{array}$} & & \multirow[b]{2}{*}{ Sig. } & \multicolumn{2}{|c|}{ Collinearity Statistics } \\
\hline & B & $\begin{array}{l}\text { Std. } \\
\text { Error }\end{array}$ & & & & Tolerance & VIF \\
\hline 1 (Constant) & 3,644 & ,768 & & 4,046 & .000 & & \\
\hline Motivasi & ,129 & .032 & 202 & 4,431 & .000 & .825 & 1,213 \\
\hline Persepsi & .117 & .026 & .202 & 5,580 & .000 & .993 & 1,007 \\
\hline Sikap konsumen & 274 & ,047 & 209 & 5,580 & ,000 & 825 & 1,212 \\
\hline
\end{tabular}

Berdasarkan uraian tabel 5 menunjukkan bahwa nilai tolerance dari masing-masing variabel adalah sebesar $0,825>0,1$ dan nilai VIF $1,212<10$. dengan demikian dapat disimpulkan bahwa tidak terjadi multikolinieritas.

Hasil Uji Heteroskedastisitas

Tabel 5. Hasil Uji Heteroskedastisitas

\begin{tabular}{|c|c|c|c|c|c|}
\hline \multirow[t]{2}{*}{ Model } & \multicolumn{2}{|c|}{$\begin{array}{c}\text { Unstandardized } \\
\text { Coefficients }\end{array}$} & \multirow{2}{*}{$\begin{array}{c}\begin{array}{c}\text { Standardized } \\
\text { Coefficients }\end{array} \\
\text { Beta }\end{array}$} & \multirow[b]{2}{*}{$\mathrm{T}$} & \multirow[b]{2}{*}{ Sig. } \\
\hline & B & Std. Error & & & \\
\hline (Constant) & 3,644 & ,768 & & 4,743 & .000 \\
\hline Motivasi & .129 & .032 & .202 & 4,046 & .000 \\
\hline Persepsi & .117 & .026 & .202 & 4,431 & .000 \\
\hline Sikap Konsumen & ,274 & ,049 & 292 & 5,850 & ,000 \\
\hline
\end{tabular}

Berdasarkan hasil tabel 4 dapat disimpulkan bahwa suatu model tidak mengalami gejala heteroskedastisitas jika nilai signifikansi $>0,05$. Taraf signifikansi masing-masing variabel adalah $>0,05$, maka tidak terjadi gejala heteroskedastisitas

Hasil Uji Regresi Linear Berganda

Tabel 6. Hasil Uji Regresi Linier Berganda

\begin{tabular}{|c|r|r|r|r|r|}
\hline Model & \multicolumn{2}{|c|}{$\begin{array}{c}\text { Unstandardized } \\
\text { Coefficients }\end{array}$} & $\begin{array}{l}\text { Standardized } \\
\text { Coefficients }\end{array}$ & \multirow{2}{*}{ T } & \\
\cline { 2 - 4 } & \multicolumn{1}{|c|}{ B } & Std. Error & \multicolumn{1}{c|}{ Beta } & & \\
\hline (Constant) & 3,644 &, 768 & & 4,046 &, 000 \\
1.Motivasi &, 129 &, 032 &, 202 & 4,431 &, 000 \\
2. Persepsi &, 117 &, 026 &, 202 & 5,850 &, 000 \\
\hline
\end{tabular}

JURNAL AKUNTANSI BARELANG

Vol.4 No. 1 Tahun 2019 


\begin{tabular}{|l|r|r|r|r|r|}
\hline $\begin{array}{l}\text { 3.Sikap } \\
\text { Konsumen }\end{array}$ &, 274 &, 047 &, 292 & 5,850 &, 000 \\
\hline a. Dependent Variable: Keputusan Pembelian
\end{tabular}
berikut:

Dari olah data pada tabel 6 dapat disusun persamaan regresi linier berganda sebagai $\mathrm{Y}=3,644+0,129 \mathrm{X} 1+0,117 \mathrm{X} 2+0,274 \mathrm{X} 3+\mathrm{e}$

Keterangan:

$\mathrm{Y}=$ Keputusan Pembelian

$\mathrm{X} 1=$ Motivasi

$\mathrm{X} 2=$ Persepsi

$\mathrm{X} 3=$ Sikap Konsumen

$\beta 0=$ Intercept $Y$

$\beta 1 \beta 2=$ Koefisien Regresi

$\mathrm{e}=$ Error atau sisa (residual

1. Nilai konstanta 3,644 Memiliki arti bahwa jika variabel motivasi, Persepsi dan Sikap Konsumen memiliki nilai 0, maka variabel keputusan Pembelian akan memiliki nilai sebesar 3,644.

2. Nilai koefisien regresi untuk variabel motivasi adalah sebesar 0,129 dan hal ini

3. menunjukkan bahwa semakin tinggi nilai variabel motivasi (X1), maka semakin tingggi nilai variabel Keputusan Pembelian. Jika variabel motivasi naik 1\% atau 1 poin, maka variabel keputusan pembelian akan meningkat sebesar 0,129 atau 12,9\%.

4. Nilai koefisien regresi untuk Persepsi adalah sebesar 0,117 dan hal ini menunjukkan bahwa semakin tinggi nilai variabel Persepsi (X2), maka semakin tingggi nilai variabel keputusan pembelian. Jika variabel persepsi naik $1 \%$ atau 1 poin, maka variabel keputusan pembelian akan meningkat sebesar 0,117 atau $11,7 \%$.

5. Nilai koefisien regresi untuk variabel sikap konsumen adalah sebesar 0,274 dan hal ini menunjukkan bahwa semakin tinggi nilai variabel Sikap Konsumen (X3), maka semakin tingggi nilai variabel keputusan pembelian. Jika variabel sikap Konsumen naik $1 \%$ atau 1 poin, maka variabel keputusan pembelian akan meningkat sebesar 0,274 atau $27,4 \%$

Hasil Uji Koefisien Determinasi $\left(\mathrm{R}^{2}\right)$

Tabel 7. Hasil Uji Koefisien Determinasi (R Square)

\begin{tabular}{|c|c|c|c|c|}
\hline Model & $\mathrm{R}$ & R Square & $\begin{array}{l}\text { Adjusted R } \\
\text { Square }\end{array}$ & $\begin{array}{l}\text { Std. Error of } \\
\text { the Estimate }\end{array}$ \\
\hline 1 & $.466^{\mathrm{a}}$ & .217 & .211 & 1.291 \\
\hline
\end{tabular}

Berdasarkan tabel 7 dapat diketahui bahwa koefisien determinasi $\left(\mathrm{R}^{2}\right)$ yang diperoleh sebesar 0,217 yang berarti besarnya peranan variabel Motivasi (X1) Persepsi (X2) dan sikap Konsumen (X3) mampu menjelaskan variabel (Y) Keputusan Pembelian sebesar 21.7\% dan sisanya $71,1 \%$ dipengaruhi oleh variabel lain yang tidak dibahas dalam penelitian ini

Hasil Uji T

Tabel 8. Hasil Uji-t

\begin{tabular}{|c|c|c|c|c|c|c|}
\hline \multirow{2}{*}{\multicolumn{2}{|c|}{ Model }} & \multicolumn{2}{|c|}{ Unstandardized Coefficients } & \multirow{2}{*}{$\begin{array}{c}\begin{array}{c}\text { Standardized } \\
\text { Coefficients }\end{array} \\
\text { Beta }\end{array}$} & \multirow[t]{2}{*}{$\mathrm{T}$} & \multirow[t]{2}{*}{ Sig. } \\
\hline & & B & Std. Error & & & \\
\hline \multirow{4}{*}{1} & (Constant) & 3,644 &, 768 & & 4,743 & ,000 \\
\hline & Motivasi &, 129 & 032 & 202 & 4,046 & 000 \\
\hline & Persepsi &, 117 &, 026 & ,202 & 4,431 &, 000 \\
\hline & Sikap Konsumen & ,274 & 047 & ,292 & 5,850 &, 000 \\
\hline
\end{tabular}


Berdasarkan tabel 8 dapat diketahui bahwa :

1. Pengujian hipotesis 1

Hipotesis pertama menyatakan bahwa motivasi berpengaruh signifikan terhadap keputusan Pembelian . Dikatakan berpengaruh karena nilai t untuk variabel motivasi adalalah positif sebesar 4,046. Dikatakan sifgnifikan karena nilai signifikan dari variabel motivasi sebesar 0,000 $<0,05$ dan nilai $\mathrm{t}$ hitung sebesar 4,046 $>\mathrm{t}$ tabel $(1,967)$. Maka diambil kesimpulan bahwa hipotesis pertama diterima.

2. Pengujian hipotesis 2

Hipotesis kedua menyatakan bahwa persepsi berpengaruh signifikan terhadap keputusan pembelian. Dikatakan berpengaruh karena nilai t hitung variabel lingkungan kerja adalah positif sebesar 4,431. Dikatakan signifikan karena nilai signifikan dari variabel lingkungan kerja sebesar $0.001<0,05$ dan nilai $t$ hitung sebesar 4,431 $>\mathrm{t}$ tabel $(1,967)$. Maka diambil kesimpulan bahwa hipotesis kedua diterima.

3) Pengujian hipotesis 3

Hipotesis ketiga menyatakan bahwa sikap konsumen berpengaruh signifikan terhadap keputusan pembelian. Dikatakan berpengaruh karena nilai t hitung variabel stres kerja adalah positif sebesar 5,850. Dikatakan signifikan karena nilai signifikan dari variabel stress sebesar $0.000<$ 0,05 dan nilai t hitung sebesar 5,850 $>\mathrm{t}$ tabel $(0,1967)$. Maka diambil kesimpulan bahwa hipotesis kedua diterima.

Hasil Uji F

Tabel 9. Hasil Uji-F

\begin{tabular}{|rl|r|r|r|r|r|}
\hline \multicolumn{1}{|l|}{ Model } & \multicolumn{1}{c|}{$\begin{array}{c}\text { Sum of } \\
\text { Squares }\end{array}$} & \multicolumn{1}{c|}{ Df } & $\begin{array}{c}\text { Mean } \\
\text { Square }\end{array}$ & F & Sig. \\
\hline \multirow{3}{*}{1} & Regression & 175,436 & 3 & 58,479 & 35,077 &, $000^{\mathrm{b}}$ \\
& Residual & 633,522 & 380 & 1,667 & & \\
\cline { 2 - 7 } & Total & 808,958 & 383 & & & \\
\hline
\end{tabular}

a. Dependent Variable: Keputusan Pembelian

b. Predictors: (Constant), motivasi, persepsi, sikap konsumen

Untuk hipotesis 4 yang menyatakan bahwa motivasi, persepsi dan sikap konsumen secara bersama-sama memiliki pengaruh yang signifikan terhadap keputusan pembelian, dapat dilihat dari tabel diatas bahwa variabel motivas, persepsi dan sikap konsumen signifikan terhadap keputusan pembelian. Dikatakan signifikan karena nilai signifikan dari variabel motivasi, persepsi dan sikap konsumen sebesar $0,000<0,05$ dan nilai $\mathrm{F}$ hitung sebesar 35,077> F tabel 2,63. Maka dapat disimpulkan bahwa hipotesis keempat diterima.

\section{Pembahasan}

Motivasi Berpengaruh Terhadap Keputusan pembelian

Berdasarkan hasil pengujian diatas dapat dilihat variabel motivasi (X1) dengan nilai koefisien regresi berganda sebesar 0,129 berpengaruh signifikan terhadap kinerja karyawan. Hal ini terlihat dari signifikan $0,000<0,05$ dan nilai t hitung 4,046 $>1,967$. Berarti hipotesis diterima. Terlihat bahwa bagi konsumen motivasi sangat penting dalam keputusan pembelian. kebutuhan dasar fisiologis yang telah terpenuhi akan sangat dimungkinkan jika para konsumen memiliki motivasi yang tinggi, dengan motivasi yang tinggi konsumen akan lebih yakin dalam setiap keputusan pembelian yang di ambil. Penelitian ini juga selaras dengan penelitian yang telah dilakukan oleh (Sisilya Truly Retor, 2014) yang berjudul "Analisis Motivasi, persepsi, Pembelajaran, dan Sikap Terhadap Keputusan Pembelian Pada PT Conbloc Indonesia Surya Manado"dengan kesimpulan bahwa motivasi berpengaruh signifikan terhadap keputusan pembelian. 
Persepsi Berpengaruh keputusan pembelian

Berdasarkan hasil pengujian diatas dapat dilihat variabel persepsi (X2) dengan nilai koefisien regresi berganda sebesar 0,117 berpengaruh signifikan terhadap keputusan pembelian. Hal ini terlihat dari signifikan $0,001<0,05$ dan nilai t hitung 4,431 $>1,967$. Berarti hipotesis diterima. Hal ini berarti bahwa mayoritas responden menjawab setuju dengan indikator kekontrasan atau perbedaan yang menyolok, kebaruan, intesitas, besar ukuran adalah hal penting yang harus di perhatikan oleh perusahaan. Penelitian ini juga selaras dengan penelitian yang telah dilakukan oleh (Arthur Adilang, Sem G. Oroh dan S. Moniharapon, 2014) yang berjudul Persepsi, Sikap, Motivasi Hedonis Terhadap Keputusan Pembelian Produk Fashion Secara Online" dengan kesimpulan bahwa Persepsi berpengaruh dengan terhadap keputusan pembelian. Sikap berpengaruh terhadap keputusan pembelian.

\section{Sikap konsumen Berpengaruh Terhadap Keputusan Pembelian}

Berdasarkan hasil pengujian diatas dapat dilihat variabel sikap konsumen (X3) dengan nilai koefisien regresi berganda sebesar 0,274 berpengaruh signifikan terhadap kinerja karyawan. Hal ini terlihat dari signifikan $0,000<0,05$ dan nilai t hitung 5,850>1,967. Berarti hipotesis diterima. Mayoritas responden setuju dengan indikator sikap memiliki Objek, konstensi sikap, sikap positif, negatif, dan netral, keyakinan, sikap intesitas sikap sebagai penyebab terjadinya sikap konsumen. Penelitian ini juga selaras dengan penelitian yang telah dilakukan oleh (Hizkia Elfran Mawey, 2013) yang berjudul "Motivasi, Persepsi dan Sikap konsumen Pengaruhnya terhadap Keputusan Pembelian Produk PT. Rajawali Nusindo Cabang Manado" dengan kesimpulan bahwa sikap berpengaruh positif dan signifikan terhadap keputusan pembelian konsumen.

Pengaruh Motivasi, Persepsi, dan Sikap Konsumen terhadap Keputusan Pembelian

Berdasarkan hasil pengujian diatas dapat dilihat variabel variabel motivasi, Persepsi dan Sikap Konsumen dengan nilai koefisien determinasi (Adjusted R Square) sebesar 0,211 atau 21,1\% pada uji F secara bersama-sama variabel motivasi, Persepsi dan Sikap Konsumen berpengaruh signifikan terhadap Keputusan Pembelian, hal ini dibuktikan dengan uji $\mathrm{F}$ secara bersama-sama dengan nilai koefisien sebesar $0,000<0,05$ dan nilai $\mathrm{F}$ hitung sebesar 35,077 $>\mathrm{F}$ tabel 2,63. Penelitian ini juga selaras dengan penelitian yang telah dilakukan oleh (Angga Arif Wibowo, Achmad Zaini, 2017) yang berjudul " Pengaruh Motivasi, Persepsi, dan Sikap Terhadap Keputusan Pembelian Pada Distro The Doff di kota pasuruan" dengan kesimpulan bahwa motivasi, persepsi dan sikap konsumen berpengaruh signifikan terhadap keputusan pembelian.

\section{SIMPULAN}

Berdasarkan hasil penelitian dan pembahasan yang telah dilakukan terhadap sluruh data yang diperoleh, maka kesimpulan yang dapat disimpulkan yang dari judul penelitian "Pengaruh Motivasi , Persepsi dan Sikap Konsumen Terhadap Keputusan Pembelian Pada PT Telekomunikasi indonesia" adalah sebagai berikut:

1. Hasil penelitian ini menunjukkan bahwa motivasi berpengaruh signifikan terhadap Keputusan Pembelian. Hal ini dapat dilihat dari nilai koefisien regresi sebesar 0,129 dengan nilai signifikansi sebesar 0,000 (lebih kecil dari nilai $\alpha=0,05$ ) dan nilai t hitung sebesar 4.046 (lebih besar dari nilai t tabel 1,967).

2. Hasil penelitian ini menunjukkan bahwa Persepsi berpengaruh signifikan terhadap Keputusan Pembelian. Hal ini dapat dilihat dari nilai koefisien regresi sebesar 0,117 dengan nilai signifikansi sebesar 0,001 (lebih kecil dari nilai $\alpha=0,05$ ) dan nilai t hitung sebesar 4,431 (lebih besar dari nilai t tabel 1,967).

3. Hasil penelitian ini menunjukkan bahwa Sikap Konsumen berpengaruh signifikan terhadap Keputusan Pembelian. Hal ini dapat dilihat dari nilai koefisien regresi sebesar 
4. 0,274 dengan nilai signifikansi sebesar 0,000 (lebih kecil dari nilai $\alpha=0,05$ ) dan nilai t hitung sebesar 5,850 (lebih besar dari nilai t tabel 1,967).

5. Berdasarkan hasil pengujian pada uji $F$ dapat dilihat bahwa secara bersama-sama motivasi, Persepsi dan Sikap Konsumen berpengaruh signifikan terhadap Keputusan Pembelian. Hal ini dapat dilihat dari nilai signifikansi sebesar 0,000 (lebih kecil dari nilai $\alpha=0,05$ ) dan nilai $\mathrm{F}$ hitung sebesar 35,077 (lebih kecil dari nilai $\mathrm{F}$ tabel 2,63).

\section{DAFTAR PUSTAKA}

Adilang, Arthur, and Dkk. 2014. "Persepsi, Sikap Dan Motivasi Hedonis Terhadap Keputusan Pembelian Produk Fashion Secara Online." 2(1): 561-70.

Fahmi, Irham. 2016. Manajemen Investasi Teori Dan Aplikasi. 1st ed. Singapura.

Mawey, Hizkia Elfran. 2013. "Motivasi, Persepsi, Dan Sikap Konsumen Perngaruhnya Terhadap Keputusan Pembelian Produk Pt Rajawali Nusindo Cabang Manado.” 1(4): 791-801.

Oentoro, Deliyanti. 2010. Manajemen Pemasaran Modern. 12th ed. Yogyakarta: Laksbang Pressindo.

Retor, Sisilya Truly. 2014. "Analisis Motivasi, Persepsi, Pembelajaran, Keyakinan Dan Sikap Terhadap Keputusan Pembelian Pada PT Conbloc Indonesia Surya Manado.” 2(3): 66475.

Sangadji, Etta Mamang, Dan, and Sopiah. 2013. Perilaku Konsumen. 1st ed. ed. Nikoemus WK. Yogyakarta: ANDI.

Sanusi, Anwar. 2011. Metodologi Penelitian Bisnis. Salemba Empat.

Sugiyono. 2012. Metode Penelitian Kuantitatif Kualitatif Dan $R \& D$. 17th ed. Bandung: ALFABETA.

. 2014. Metode Penelitian Kuantitatif Kualitatif Dan R\&D. 21st ed. Bandung: Alfabeta.

Tatik Suryani. 2013. Perilaku Konsumen Di Era Internet Implikasinya Pada Strategi Pemasaran. 1st ed. Yogyakarta: Graha Ilmu.

Tompunu, Merna M.M. 2014. "Analisis Motivasi, Persepsi, Pembelian, Dan Sikap Konsumen Pengaruhnya Terhadap Keputusan Pembelian Di Kfc Bahu Mall Manado.” 2(3): 610-21.

Wibowo, Angga arif, and Achmad Zaini. 2017. "Pengaruh Motivasi, Persepsi Dan Sikap Terhadap Keputusan Pembelian Pada Distro The Doff Di Kota Pasuruan." : 96-97. 